\title{
Growth performance of roselle (Hibiscus sabdariffa) under application of food waste compost and $\mathrm{Fe}_{3} \mathrm{O}_{4}$ nanoparticle treatment
}

\author{
Syahnaz Ad-Din Naquib bin Shuhaimi ${ }^{1} \cdot$ Devagi Kanakaraju $^{1}\left(\mathbb{0} \cdot\right.$ Hollena Nori $^{1}$
}

Received: 30 November 2018 / Accepted: 23 September 2019 / Published online: 1 October 2019

(c) The Author(s) 2019

\begin{abstract}
Purpose Utilization of food waste as composting materials offers a sustainable solution to manage waste and reduce reliance on fertilizers.

Method This study is focused on the efficiency of food waste compost and the effect of the addition of magnetite $\left(\mathrm{Fe}_{3} \mathrm{O}_{4}\right)$ nanoparticles on the growth and heavy metals uptake by roselle (Hibiscus sabdariffa) for the cultivation period of 127 days. Five different treatments were applied, namely soil (S), food waste compost $(\mathrm{F})$, a mixture of soil and $\mathrm{Fe}_{3} \mathrm{O}_{4}(\mathrm{SM})$, a mixture of soil and food waste compost (SF), and a mixture of soil, food waste compost, and $\mathrm{Fe}_{3} \mathrm{O}_{4}(\mathrm{SFM})$.

Results After 127 days of cultivation, the plant height averaged at $803 \mathrm{~mm}$ with 26 leaves produced across all treatments. Total leaf area, fruit production, and biomass yield were different $(P<0.05)$ among the treatments. Roselle crops grown under soil and food waste (SF) media produced the highest yield (12.15 g/plant), the most number of fruits (11 fruits/plant), and the highest leaf area $\left(1200 \mathrm{~cm}^{2} /\right.$ plant $)$. The accumulation of heavy metals in plant tissues was lower than the toxicity levels. There was no difference in the heavy metal content in all growing media, except for $\mathrm{Ni}, \mathrm{Mn}$, and $\mathrm{Pb}$. Roselle crops applied with $\mathrm{Fe}_{3} \mathrm{O}_{4}$ showed no difference $(P>0.05)$ from its control (without $\mathrm{Fe}_{3} \mathrm{O}_{4}$ ) in relation to growth performance.

Conclusion The findings of this study showed that food waste can be applied in composting to promote plant growth. Therefore, it can be considered as a substitute for chemical fertilizers. Meanwhile, the application of $\mathrm{Fe}_{3} \mathrm{O}_{4}$ appeared to be experimental-condition dependent.
\end{abstract}

Keywords Food waste $\cdot$ Magnetite $\cdot$ Organic fertilizer $\cdot$ Plant growth $\cdot$ Soil amendment

\section{Introduction}

Food waste (FW) surplus, which is estimated to be over one million tons every year, is commonly managed via landfilling. Landfilling is regarded as an environmentally unsustainable solution due to its high energy requirement and large land space utilization (Moh and Manaf 2014; Chew et al. 2018). In Malaysia, FW is classified under municipal solid waste, which accounts for $45 \%$ of the total waste produced (Manaf et al. 2009; Aja and Al-Kayiem 2014). Landfilling has been the most preferred technique for handling 80-95\% of the municipal solid waste in Malaysia (Aja and Al-Kayiem 2014). According to Jereme et al. (2013), Malaysians

Devagi Kanakaraju

kdevagi@unimas.my

1 Faculty of Resource Science and Technology, Universiti Malaysia Sarawak, 94300 Kota Samarahan, Sarawak, Malaysia end up throwing up to 930 tons of unconsumed food daily, and most of these food wastes are generated by households, wet and night markets, restaurants, hotels, and others.

As opposed to landfilling, composting may offer a sustainable and eco-friendly solution to overcome these issues, apart from enhancing soil productivity, yield, and growth of crops (Petersen et al. 2003), and reducing reliance on fertilizers (Lin et al. 2013). Many countries have considered turning FW into compost as a way to overcome disposing FW in landfills or incineration (Cerda et al. 2018). Composting can be regarded as an effective way to handle FW by turning them into value-added products for agricultural application. By converting FW into compost, the organic contents in FW, such as carbohydrates, starch, cellulose, proteins, lipids, as well as nutrients (e.g., nitrogen and phosphorus) can be utilized as organic fertilizers or as soil amendments.

Various factors may, however, contribute to the quality of FW compost as the sources of FW vary by their heterogeneous compositions, sources, and the eating habits of 
consumers (Cerda et al. 2018). Several studies have concluded that when FW compost is applied as soil additive, it promotes plant growth and improves biomass and nutrition provision (Choy et al. 2015; Ronga et al. 2016; Kaur et al. 2017). Nevertheless, the quality of the food compost produced depends on various factors, such as moisture content, carbon and nitrogen ratio, aeration, porosity, bulk density, and organic matter (Azim et al. 2018; Waqas et al. 2018). In addition, the effectiveness of compost as soil additive depends on its ability to reduce metal bioavailability or uptake by plants or crops by retaining them in bound form (Adejumo et al. 2018). Therefore, investigation of heavy metals in plants grown using compost-amended soil is vital to ascertain no sign of metal toxicity.

Nanoparticles are emerging to overcome agricultural issues, such as low soil fertility, pest attack, stagnancy of crop production, poor irrigation, climate uncertainty, and polluted soil (Baker et al. 2017). Nanoparticles can enhance crop growth and simultaneously act as fungicides, insecticides, herbicides, and pesticides (Parisi et al. 2015). For example, $\mathrm{ZnO}$ nanoparticles were used for seed germination and root of Chick pea (Cicer arietinum) (Pandey et al. 2010) while magnetite $\left(\mathrm{Fe}_{3} \mathrm{O}_{4}\right)$ was used for pumpkin (Cucurbita maxima) growth (Zhu et al. 2008). Among various nanoparticles, $\mathrm{Fe}_{3} \mathrm{O}_{4}$ is useful in agricultural application due to its ability to undergo absorption, translocation, and accumulation for plant growth promotion (Wang et al. 2011). Nevertheless, the performance of $\mathrm{Fe}_{3} \mathrm{O}_{4}$ is dependent on its properties, types of plants, and the specific conditions of the experiment itself (Lin and Xing 2007). Previous studies showed that the effects of $\mathrm{Fe}_{3} \mathrm{O}_{4}$ on the growth of plants vary from inhibition to promotion, as well as having no effect (Zhu et al. 2008; Wang et al. 2011; Konatea et al. 2018). Studies on the application of $\mathrm{Fe}_{3} \mathrm{O}_{4}$ nanoparticles are still lacking, particularly on its ability to enhance crop growth when incorporated into soil medium.

This study chose tea leaves, coffee grounds, lemongrass leaves, eggshells, and banana peels as they are readily available, produced in large quantities, and contain nutrients, such as nitrogen, phosphorus, and potassium. Their essential elements content, natural liming properties, and fungicides behavior have been contemplated to be beneficial in the plant growth mechanism (Morikawa and Saigusa 2011; Kalemelawa et al. 2012; Abd El-Azeem et al. 2013; Al-Yousef 2013). Although extensive studies have been conducted on FW composting, very limited information is available on the combined effects of $\mathrm{FW}$ and $\mathrm{Fe}_{3} \mathrm{O}_{4}$ on plant growth.

The objective of this study was to evaluate the performance of FW compost and $\mathrm{Fe}_{3} \mathrm{O}_{4}$ on the growth of roselle (Hibiscus sabdariffa) within 127 days of cultivation. Various combinations of treatments were investigated, namely soil (S), FW compost (F), mixture of soil and $\mathrm{Fe}_{3} \mathrm{O}_{4}(\mathrm{SM})$, mixture of soil and FW compost (SF), and mixture of soil, FW compost, and $\mathrm{Fe}_{3} \mathrm{O}_{4}$ (SFM) to determine their effects on the growth of roselle, measured in terms of height, number of leaves, number of fruits, dry weight of fruits, and total leaf area.

\section{Materials and methods}

\section{Preparation of food waste materials}

The FW compost used in this study consisted of tea leaves, coffee grounds, banana peels, eggshells, and lemongrass leaves. These wastes were collected from cafeterias in Universiti Malaysia Sarawak and food stalls in Desa Ilmu, Kota Samarahan, Sarawak. All samples were air dried at ambient temperature of $\sim 30^{\circ} \mathrm{C}$. Coffee grounds, banana peels, and eggshells were then oven-dried to overcome problems associated with fungi and pests (Table 1). Each waste sample was ground to pass through a 2.0-mm sieve (Quest Scientific FGR-350). The waste samples of tea leaves, coffee grounds, banana peels, eggshells, and lemongrass leaves were then mixed (on a volume basis) at $41 \%, 13 \%, 20 \%, 13 \%$, and $13 \%$, respectively, to form a composting media (Guidoni et al. 2018).

\section{Experimental design and husbandry}

A completely randomized design experiment was initiated using five growing media, namely soil (S), food waste compost (FW), soil + magnetite (SM), soil + food waste compost (SF), and soil + food waste compost + magnetite (SFM) in
Table 1 Food waste compost preparation

\begin{tabular}{lll}
\hline Type of waste & Preparation & Remarks \\
\hline Tea & Air dried for 5 days & - \\
Coffee & Air dried for 5 days & Fungi grown before being oven-dried \\
& Oven-dried $\left(60^{\circ} \mathrm{C}\right)$ for $12 \mathrm{~h}$ & \\
Banana peel & Air dried for 5 days & Pest attracted to waste before being oven-dried \\
& Oven-dried $\left(80^{\circ} \mathrm{C}\right)$ for $12 \mathrm{~h}$ & \\
Egg shell & Air dried for 3 days & Unpleasant odor and pest attracted before \\
& Oven-dried $\left(80^{\circ} \mathrm{C}\right)$ for $6 \mathrm{~h}$ & being oven-dried \\
Lemongrass leaves & Air dried for 3 days & - \\
\hline
\end{tabular}


four replicates. The soil (S) media was a potting mixture of red burnt soil, humus compound, burned husks, coco peat, charcoal, and river sand, which was manufactured by Kean Being Lee Industries (M) Sdn. Bhd. The magnetite powder $\left(\mathrm{Fe}_{3} \mathrm{O}_{4}\right)$ nanoparticles were synthesized according to the procedures published by Kanakaraju et al. (2018). Plastic pots $(6.0 \mathrm{~L})$ were filled with these growing media according to the ratio by volume of each component (Table 2).

Fifty seeds of the roselle plant were sown in a plastic tray $(0.3 \times 0.25 \times 0.1 \mathrm{~m})$ filled with a mixture of coco peat and top soil (1:1 by volume). The ratio of $1: 1$ was chosen based on minor modifications to the procedures proposed by Sutari et al. (2018). The tray was placed in a shaded pavement area outside the laboratory at the Faculty of Resource Science and Technology, Universiti Malaysia Sarawak, Kota Samarahan, Malaysia. After 15 days, roselle seedlings that produced four leaves were selected and transplanted into 6. $0 \mathrm{~L}$ pots containing each growing medium (S, F, SM, SF, and SFM). In each pot, only one plant was transplanted and used for detailed measurement. After 4 weeks from the sowing day, the pots were placed in an open area outside the laboratory, where the plants received full sunlight $(5 \mathrm{~h}$ of sunshine per day). In this location, the average daily humidity was $87 \%$. The mean daily minimum and maximum air temperatures were at $24{ }^{\circ} \mathrm{C}$ and $32{ }^{\circ} \mathrm{C}$, respectively. The mean monthly rainfall was $462 \mathrm{~mm}$ throughout the growing period (127 days). Except for rainy days, the pots were watered daily at $\sim 500 \mathrm{~mL} /$ pot.

\section{Measurement of plant growth and analysis of heavy metal uptake}

Plant height and the number of leaves were measured and counted at 7-day intervals for a period of 112 days. The crop entered into the flowering phase after 92 days after sowing. Following this event, the number of fruits produced was counted at weekly interval until the time of harvest. The roselle plants were harvested after 127 days after sowing. Following harvest, the above ground biomass was separated into fruits, leaves, and stems. Total leaf area was measured using a leaf area meter (AT Delta-T Devices, UK). A piece of $25 \mathrm{~cm}^{2}$ paper was used to calibrate the instrument prior to measurement. The dry weight of the fruits, leaves, and stems were measured using an electronic scale after these yield components were oven-dried $\left(70^{\circ} \mathrm{C}\right)$ for 2 days. Each component was then ground into solid powder for analysis of heavy metals.

The plants, top soil, and FW compost samples were acid digested using procedures described by Uddin et al. (2016). Specifically, the samples were digested using a mixture of concentrated $\mathrm{HNO}_{3}$ and $\mathrm{HCl}$ (ratio of 1:3). Approximately $1 \mathrm{~g}$ of dry weight plant sample was added into a 50-mL Pyrex beaker and heated on a hotplate at $95{ }^{\circ} \mathrm{C}$. Then, the acids were added to the sample and heated for $5 \mathrm{~h}$. The resultant solution was filtered using a filter paper and diluted to $100 \mathrm{~mL}$ of solution. The concentrations of $\mathrm{Pb}, \mathrm{Cd}, \mathrm{Ni}, \mathrm{Al}, \mathrm{Cu}, \mathrm{Mn}, \mathrm{Zn}$, and $\mathrm{Fe}$ were determined using Flame Atomic Absorption Spectroscopy (FAAS) (iCE 3000 Thermo Scientific).

\section{Nutrient analysis}

The growing media (before and after roselle cultivation) and plant tissues were analyzed for nitrogen $(\mathrm{N})$, phosphorus $(\mathrm{P})$, and potassium $(\mathrm{K})$ contents. Total nitrogen was analyzed using the Kjedahl method, which comprised digestion, distillation, and titration. Available phosphorus was determined using the Bray and Krutz II method. As for potassium content, the samples were digested according to the EPA Method 3050B. The FAAS was used to analyze the potassium concentration in the samples.

\section{Iron leaching test}

This experiment was conducted only with the soil + magnetite (SM) and soil + food waste compost + magnetite (SFM) growing media. Magnetite was applied a week after transplanting (22 days after sowing) to allow the crops to acclimatize, as well as to avoid transplanting shock. The purpose of magnetite addition was to determine its effect on the growth of roselle. Given that iron $(\mathrm{Fe})$ is one of the mineral components of magnetite, the aim of this experiment

Table 2 Preparation of growing media according to the ratio by volume of each component

\begin{tabular}{lll}
\hline Growing media & Content & Description \\
\hline S & Soil & Pots were filled with soil \\
F & Food waste compost & Pots were filled with FW compost \\
SM & Soil + magnetite & Pots were filled with soil and magnetite powder \\
& & $\left(\mathrm{Fe}_{3} \mathrm{O}_{4}\right)$ at $1: 0.25$ \\
SF & Soil + food waste compost & Pots were filled with soil and FW compost at 1:1 \\
SFM & Soil + food waste compost + magnetite & Pots were filled soil, FW and magnetite at 1:1:0.25 \\
\hline
\end{tabular}

${ }^{\text {a} N a m k o o n g ~ e t ~ a l . ~} 2002$ 


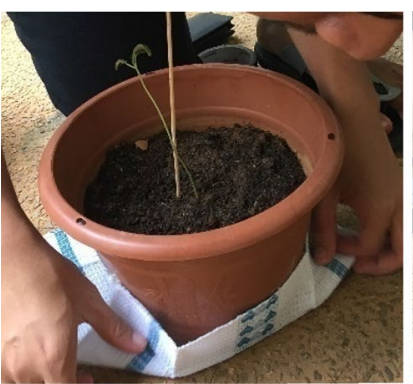

(a)

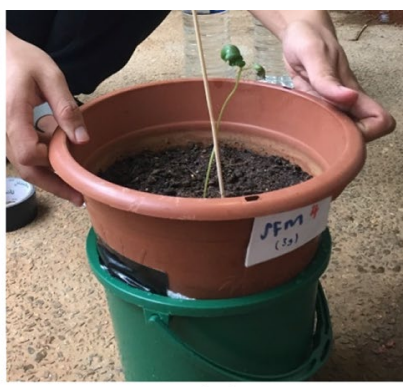

(b)
Fig. 1 Iron leaching pot preparation, a bottom part of the pot covered with cotton cloth, $\mathbf{b}$ covered pot was stacked onto smaller pail

was to assess the leaching potential of $\mathrm{Fe}$ to the environment following its application to the growing media.

The bottom of the pot was covered with cotton cloth to prevent medium (soil or food waste compost) erosion into the leachate, as shown in Fig. 1. Then, the pot was placed on the small pail to collect the leachate. The leachate was formed from the drainage of irrigation. The leachate was collected once a week and iron leaching trend was monitored for 17 weeks (127 days) of plant growth. The leachate was digested according to EPA Method (3010A). Then, the level of Fe content in the leachate was determined using FAAS.

\section{Statistical analysis}

All variates were analyzed using the one-way analysis of variance (ANOVA). Treatment means were compared using the Turkey test whenever the ANOVA indicated that the differences among treatments presented as $P<0.05$. Standard errors of the mean were reported for each measured variable.

\section{Results and discussion}

\section{Plant height}

Crops grown in all media started to show a sharp increment in plant height after 85 days after sowing (Fig. 2). In most treatments, the growth pattern appeared to be sigmoidal. The growing media did not affect the height of the roselle plants $(P>0.05)$. These plants reached the average height of 803 $( \pm 46.2) \mathrm{mm}$ after 127 days after sowing in all treatments.

Food waste (F) medium was highly aerated and provided more porous segments (Ruggieri et al. 2009), which might not have been suitable for long-term plant growth, despite being an essential characteristic for seed germination. Optimum macroporosity could influence the water retention potential to the medium compactness, resulting in an improved plant growth performance (Drewry et al. 2008). Thus, soil (S) may provide a better porosity compared with

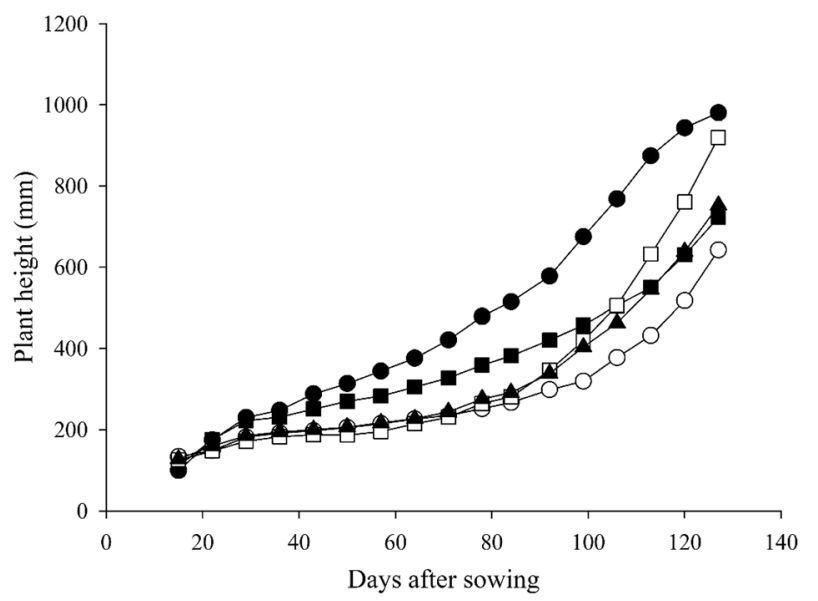

Fig. 2 The height of roselle plants grown under different types of growing media at Universiti Malaysia Sarawak. S (filled circle), F (open circle), SM (filled square), SF (open square), SFM (filled triangle). $S$ soil, $F$ food waste compost, $S M$ soil + magnetite, $S F$ soil + food waste compost, $S F M$ soil + food waste compost + magnetite

food compost alone. Potting mixed soil contained air porosity of $25-30 \%$ and water holding capacity of $~ 36 \%$ (Beardsell et al. 1979). Crops cultivated in soil and food waste compost (SF) showed an exponential growth after 99 days and began to outperform the plants grown in F, SM, and SFM media.

\section{Leaf production}

The total number of leaves did not differ among the treatments $(P>0.05)$. Across all treatments, the crop produced $27 \pm 1.4$ leaves after 127 days after sowing (Fig. 3). The production of leaves was indicative of the plant development and it is independent of plant growth. The appearance of leaves started to increase exponentially after 99 days for crops cultivated in SF media and 106 days for those grown in food waste compost $(\mathrm{F})$. It is believed that during this time, the plants have produced secondary leaves and have begun to expand their canopy, where they will vigorously compete for light and nutrient. Therefore, the rate of leaf production would determine its success in establishment. In these treatments (SF and F media), plants that formed secondary leaves earlier than plants in other media have the advantage of capturing more incoming radiation through the expansion of the canopy.

\section{Total leaf area}

The total leaf area was measured following harvest at 127 days after sowing (Fig. 4). Treatments showed significant differences between SF and SM crops at $P<0.05$ (Fig. 4). As expected, SF crops with total leaves 


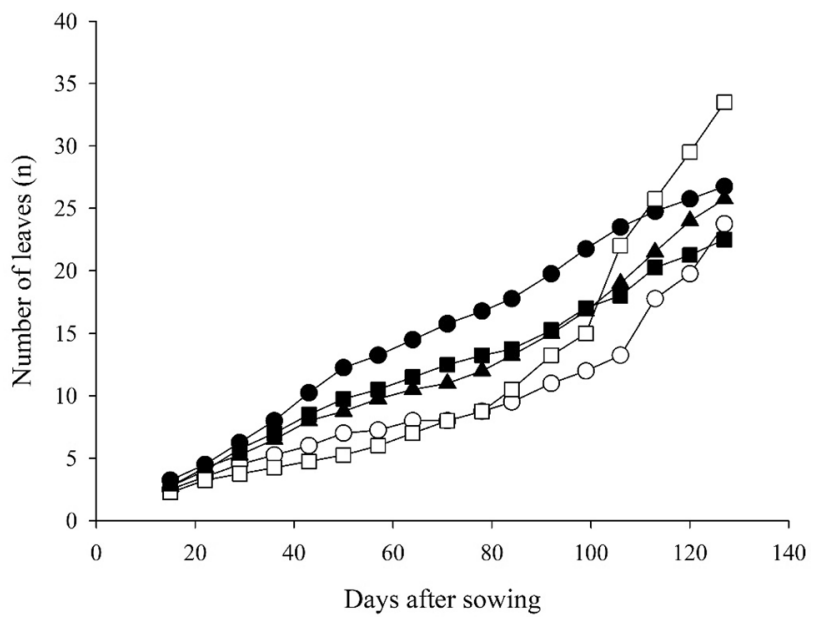

Fig. 3 Total leaf production of roselle plants grown under different types of growing media at Universiti Malaysia Sarawak. S (filled circle), F (open circle), SM (filled square), SF (open square), SFM (filled triangle). $S$ Soil, $F$ food waste compost, $S M$ soil + magnetite, $S F$ soil + food waste compost, SFM soil + food waste compost + magnetite

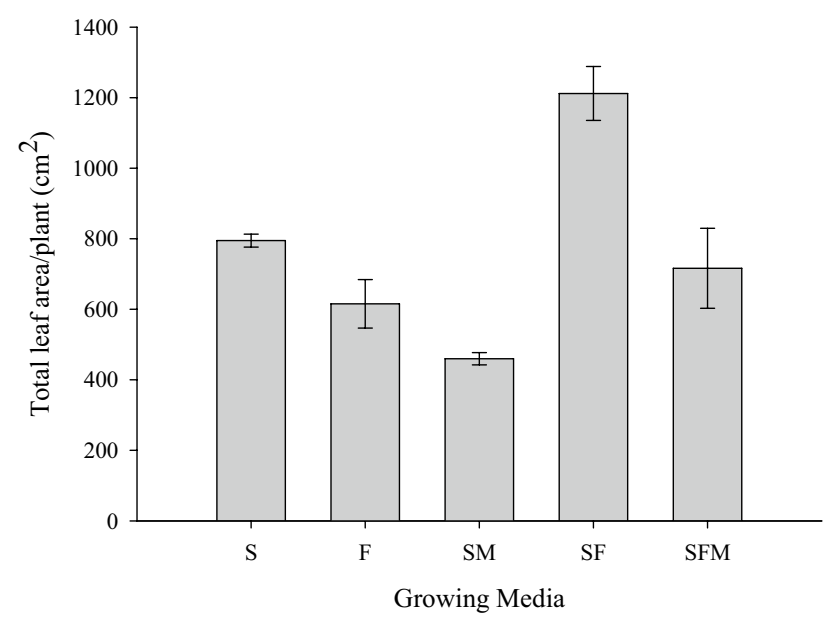

Fig. 4 Total leaf area after 127 days of roselle cultivation in different types of growing media at Universiti Malaysia Sarawak. $S$ soil, $F$ food waste compost, $S M$ soil + magnetite, $S F$ soil + food waste compost, $S F M$ soil + food waste compost + magnetite. Bars represented standard error of the mean for each growing media

of $34 \pm 2.5 \mathrm{~cm}^{2}$ (Fig. 3) gave the largest leaf area of $1212 \pm 160.0 \mathrm{~cm}^{2}$ (Fig. 4). In contrast, SM crops have a canopy size of $460 \pm 34.4 \mathrm{~cm}^{2}$ because they only produced $23 \pm 1.3 \mathrm{~cm}^{2}$ leaves at the time of harvest. Thus, the addition of FW compost into the soil at 1:1 volume ratio has elevated the growth performance of roselle crop. The FW compost supplied additional macronutrients to the crop, which promoted both vegetative and reproductive growth. In addition, the results from the analyses of nitrogen, phosphorus, and potassium contents showed that these macronutrients were present in large amounts in FW compost (F) (refer to Fig. 6).

\section{Number of fruits}

The final numbers of fruits produced were varied among the growing media $(P<0.01)$ (Fig. 5). The first fruit was initiated after 92 days for crops cultivated in soil (S), and soil and food waste compost (SF). At 106 days after sowing, crops sown in SF media began to produce fruits exponentially and outnumbered the production of crops in other treatments. As a result, crops in SF media produced the highest number of fruits $(11 \pm 1.1$ fruits $)$ at 127 days of growth. The ability of SF crops to produce more fruits could be related to its early canopy establishment (Fig. 3). SF crops produced secondary leaves earlier (after 99 days) compared with crops from other treatments. The production of secondary leaves led to the formation of branches within the plants. Consequently, more growing points were available for fruit initiation. Roselle crops grown in SM media showed the slowest progress in fruit production. Its productivity started only after 99 days after sowing, and the rate of fruit production was only one fruit per week. Thus, following the observation period of 4 weeks, this treatment has only yielded up to $4 \pm 0.8$ fruits at day 127 and recorded the lowest number of fruits among all treatments.

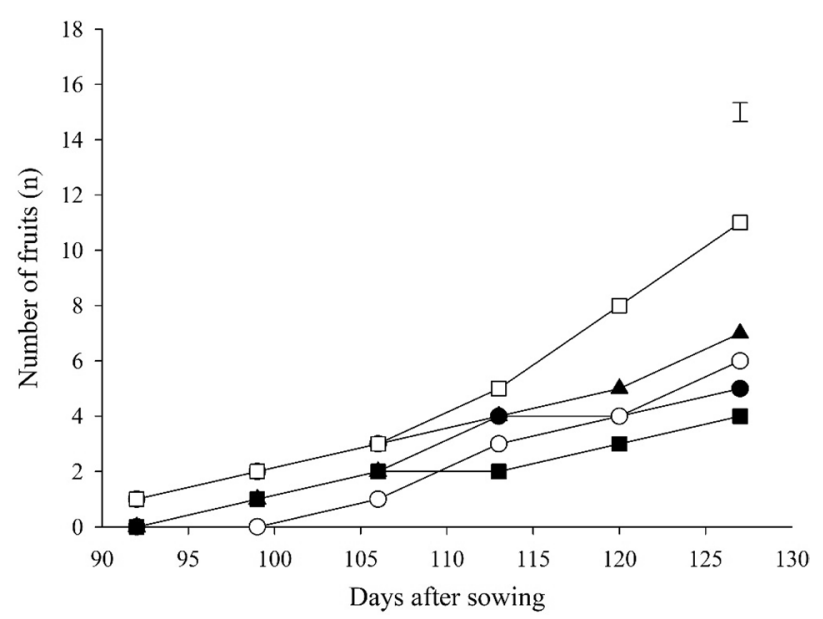

Fig. 5 Number of fruits produced by roselle plants grown under different types of growing media at Universiti Malaysia Sarawak. S (filled circle), F (ipen circle), SM (filled square), SF (open square), SFM (filled triangle). $S$ soil, $F$ food waste compost, $S M$ soil + magnetite, $S F$ soil+food waste compost, $S F M$ soil + food waste compost + magnetite. Bar represents pooled standard error of the mean where treatments were different $(P<0.01)$ 


\section{Yield}

The dry matter yield of fruits and vegetative components of these roselle plants were different $(P<0.05)$ among all treatments (Table 3 ). For fruit production, crops cultivated under S, F, and SFM media produced an average biomass of $1.78 \mathrm{~g} /$ plant. The mixture of both soil and FW compost was able to supply additional nutrients and improve the porosity of the soil. These conditions, in turn, increased the water infiltration into the soil, root penetration, crop nutrient uptake, and water uptake. In contrast, the growing media based on food waste compost alone (F) and soil + magnetite (SM) were inadequate to support the growth of roselle crops (Figs. 2, 3, 4 and 5), and consequently, giving the lowest fruit yield ( $\sim 0.46 \mathrm{~g} / \mathrm{plant})$. Total dry matter production for crops cultivated in S and SF media gave the highest aboveground biomass of $\sim 11.37 \mathrm{~g} / \mathrm{plant}$, which was contributed by the heaviest weight of fruits, leaves, and stems (Table 3).

\section{Effect of $\mathrm{Fe}_{3} \mathrm{O}_{4}$ on plant growth}

The growth performance in response to magnetite application was compared between roselle crops cultivated in soil + magnetite (SM), and its control, soil (S) growing media. The results showed that crops grown merely in soil performed better without the application of $\mathrm{Fe}_{3} \mathrm{O}_{4}$. For example, the canopy size of $\mathrm{S}$ crops was bigger $\left(795 \pm 36.8 \mathrm{~cm}^{2}\right)$ than the canopy size of SM crops $\left(460 \pm 34.4 \mathrm{~cm}^{2}\right)$ (Fig. 4). Crops in $\mathrm{S}$ medium produced slightly more fruits $(5 \pm 0.3$ fruits) than those in SM media ( $4 \pm 0.4$ fruits) (Fig. 5). The total aboveground biomass in $\mathrm{S}$ crops was also two times heavier $(10.59 \pm 0.647 \mathrm{~g})$ than the SM crops $(5.17 \pm 0.475 \mathrm{~g})$ (Table 3).

Similarly, the comparison between SFM and its control SF showed that the addition of $\mathrm{Fe}_{3} \mathrm{O}_{4}$ into the growing medium has reduced the yielding ability of roselle crops. For example, SFM crops yielded only $7 \pm 1.7$ fruits compared with SF crops (11 \pm 1.1 fruits) after 127 days (Fig. 5). In addition, the total aboveground biomass produced by SFM crops was much lower, at $7.03 \pm 2.541 \mathrm{~g} /$

Table 3 Dry matter yield (g) after 127 days of roselle cultivation in different types of growing media at Universiti Malaysia Sarawak

\begin{tabular}{llll}
\hline Growing media & $\begin{array}{l}\text { Fruit dry mat- } \\
\text { ter } \pm \text { SEM }(\mathrm{g})\end{array}$ & $\begin{array}{l}\text { Leaves }+ \text { stem dry } \\
\text { matter } \pm \text { SEM }(\mathrm{g})\end{array}$ & $\begin{array}{l}\text { Total dry } \\
\text { matter } \pm \text { SEM } \\
(\mathrm{g})\end{array}$ \\
\hline $\mathrm{S}$ & $1.85 \pm 0.232$ & $8.73 \pm 0.839$ & $10.58 \pm 0.647$ \\
$\mathrm{~F}$ & $0.45 \pm 0.241$ & $4.14 \pm 1.112$ & $4.59 \pm 1.255$ \\
$\mathrm{SM}$ & $0.47 \pm 0.083$ & $4.69 \pm 0.474$ & $5.17 \pm 0.475$ \\
$\mathrm{SF}$ & $2.15 \pm 0.671$ & $10.00 \pm 1.685$ & $12.15 \pm 2.343$ \\
SFM & $1.33 \pm 0.602$ & $5.70 \pm 1.943$ & $7.03 \pm 2.541$ \\
$P$ level & $<0.05$ & $<0.05$ & $<0.05$ \\
\hline
\end{tabular}

plant compared with the total aboveground biomass produced by SF crops $(12.15 \pm 2.343 \mathrm{~g} / \mathrm{plant}$ ) (Table 3$)$. Crops grown in SFM media also produced a smaller canopy size of $716 \pm 226.8 \mathrm{~cm}^{2}$ compared to $1212 \pm 153.0 \mathrm{~cm}^{2}$ from SF treatment (Fig. 4).

Roselle plants could be deduced to demonstrate low tolerance to direct application of $\mathrm{Fe}_{3} \mathrm{O}_{4}$. This could be due to the $\mathrm{Fe}_{3} \mathrm{O}_{4}$ powder having no attachment to the soil, and also likely due to the non-optimized amount of $\mathrm{Fe}_{3} \mathrm{O}_{4}$. This observation corroborates the results in a study reported by Zhu et al. (2008), whereby the addition of $\mathrm{Fe}_{3} \mathrm{O}_{4}$ in soil did not favor the growth of pumpkin.

\section{Nutrients and plant tissue analysis}

In all growing media, the levels of nitrogen, phosphorus, and potassium content were higher prior to crop cultivation (initial) compared with post-harvest (Fig. 6a-c). The initial nitrogen content in SF media was $342.8 \mathrm{mg} / \mathrm{kg}$, which reduced to $290.2 \mathrm{mg} / \mathrm{kg}$ after 127 days (post-harvest) (Fig. 6a). The declining nutrient level as a function of time is expected as the loss of nutrients was accounted for from the uptake by plants and leaching. In addition, the cultivation of roselle during the wet season (total precipitation of $1848 \mathrm{~mm}$ throughout the growing period) is believed to be the main cause of nutrient leaching. However, the amounts of nitrogen, phosphorus, and potassium losses from the growing media via leaching and plant uptake were not assessed in this present study, and should be considered in future work.

The initial contents of all macronutrients were in abundance in the food waste compost (F) media, with $938.75 \mathrm{mg} / \mathrm{kg}$ of nitrogen, $2.09 \mathrm{mg} / \mathrm{kg}$ of phosphorus, and $78.68 \mathrm{mg} / \mathrm{kg}$ of potassium. The inclusion of banana peels, which constituted the second largest component in the food waste compost, could have contributed to the high level of potassium. Banana peels provide potassium nutrition, which is beneficial for fruit development (Kalemelawa et al. 2012). Nevertheless, the nutrient compositions for the individual components that make up the food waste, namely tea leaves, coffee grounds, banana peels, eggshells, and lemongrass leaves were not quantified. This was an oversight in this study and therefore, should be included in future study. In plant tissues, the concentrations of phosphorus and potassium were found to be the highest in the soil (S) treatment (Fig. 6b-c). The mobility of the phosphate ions in soil could have increased the phosphorus uptake by the plants through rhizosphere acidification and root proliferation, which provide enzyme-catalyzed hydrolysis to secrete the organic phosphorus (Jing et al. 2010; Shen et al. 2011). 

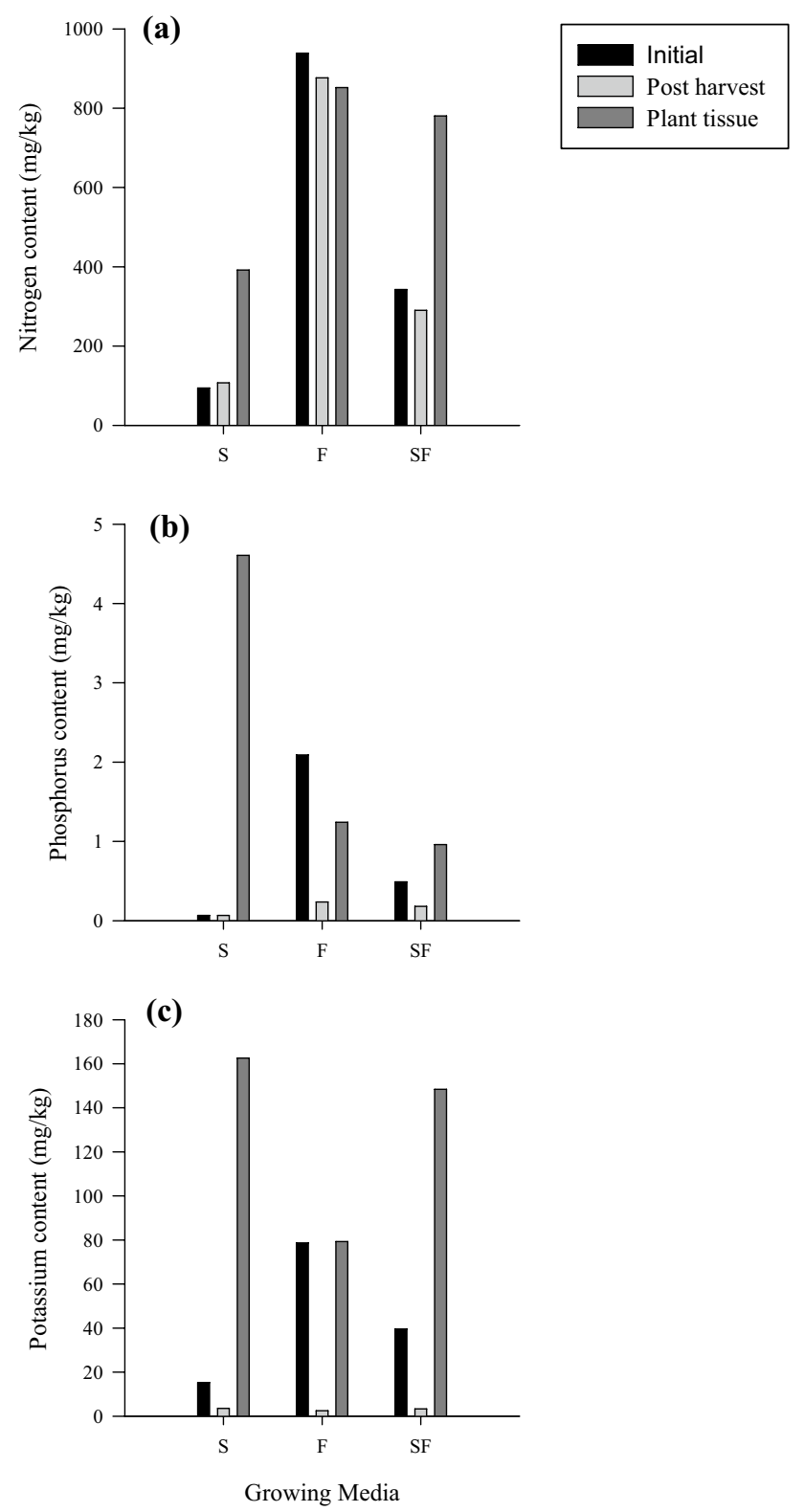

Fig. 6 Macronutrient content of a nitrogen, b phosphorus, $\mathbf{c}$ potassium measured at initial (prior to cultivation), post-harvest (127 days after sowing), and in the plant tissue (127 days after sowing) for three different growing media. $S$ soil, $F$ food waste compost, $S F$ soil + food waste compost

\section{Accumulation of heavy metals in plant tissue}

The chemical properties of the top soil and FW compost are presented in Table 4. FW compost recorded a slightly higher $\mathrm{pH}$ than the top soil. The basic condition of FW compost could be attributed to the eggshells and banana peels, which could serve as a liming material (King'ori 2011) and an alkalinity agent with great acidic controlling properties (Barreira et al. 2008), respectively. The top soil recorded a higher concentration of metals compared to FW compost.
Table 4 Chemical properties of top soil and FW compost

\begin{tabular}{lll}
\hline Chemical properties & Top soil & FW compost \\
\hline $\mathrm{pH}$ & $7.1 \pm 0.02$ & $8.5 \pm 0.03$ \\
Organic matter (\%) & $20.49 \pm 1.03$ & $25.41 \pm 0.16$ \\
Metals $(\mathrm{mg} / \mathrm{kg})$ & & \\
$\mathrm{Pb}$ & 6.85 & n.d \\
$\mathrm{Cd}$ & $\mathrm{n} . \mathrm{d}$ & n.d \\
$\mathrm{Ni}$ & 0.07 & 0.01 \\
$\mathrm{Al}$ & 313.65 & 88.71 \\
$\mathrm{Cu}$ & 0.34 & 0.09 \\
$\mathrm{Mn}$ & 5.26 & 1.71 \\
$\mathrm{Zn}$ & 0.80 & 0.31 \\
$\mathrm{Fe}$ & 792.42 & 8.46 \\
\hline
\end{tabular}

$n . d$ not detected

Iron $(\mathrm{Fe})$ and aluminum $(\mathrm{Al})$ were found to be present in elevated concentrations in the top soil. In the case of FW compost, $\mathrm{Al}$ and $\mathrm{Fe}$ were detected to be high, but their concentrations were relatively lower than those in the top soil.

The concentrations of lead $(\mathrm{Pb})$, cadmium $(\mathrm{Cd})$, and copper $(\mathrm{Cu})$ found in roselle crops were negligible $(0-0.05 \mathrm{mg} /$ $\mathrm{kg}$ ) (Fig. 7). With the exception of SFM treatment, $\mathrm{Pb}$ was not detected in roselle plant tissues. In contrast, a previous study reported that $\mathrm{Pb}$ was detected in roselle plant tissues from the application of organic manure into soil (Wuana and Mbasugh 2014). The initial sample of growing media did not indicate the presence of $\mathrm{Cd}$, but after 127 days of cultivation, the presence of $\mathrm{Cd}$ could be associated with organic matter and carbonate. This association provided a mobility pathway for $\mathrm{Cd}$ to be taken up by the plant, together with iron $(\mathrm{Fe})$ mineral dissolution (Muehe et al. 2013). Hence, $\mathrm{Cd}$ is known as a mineral-associated contaminant.

Crops grown merely on soil (S) and food waste compost (F) have extracted the least amount of nickel (Ni) (0.11 and $0.15 \mathrm{mg} / \mathrm{kg}$, respectively) compared to crops grown in the rest of the growing media $(\sim 0.22 \mathrm{mg} / \mathrm{kg})$. The highest level of manganese $(\mathrm{Mn})(1.44 \mathrm{mg} / \mathrm{kg})$ was found in crops cultivated in food waste compost (F), followed by SFM crops $(0.74 \mathrm{mg} / \mathrm{kg})$. The concentrations of zinc $(\mathrm{Zn})$ and $\mathrm{Fe}$ were 0.59 and $1.62 \mathrm{mg} / \mathrm{kg}$, respectively, across all growing media. $\mathrm{Fe}$ content in plant tissues was higher compared with the contents of $\mathrm{Cu}, \mathrm{Zn}$, and $\mathrm{Pb}$, which are similar to the results reported by Chiroma et al. (2012). This could be due to the high possibility of $\mathrm{Fe}$ strategizing its translocation from the growing medium to the plant tissue, mainly on the interaction of ferric chelate reductase, which ended up mostly in the leaf chloroplast (Jeong and Connolly 2009).

Among all heavy metals detected, aluminum (Al) was present in the highest amount of $2.39 \mathrm{mg} / \mathrm{kg}$ across all growing media. However, the presence of $\mathrm{Al}$ in plant tissues can be considered as low. This is because $\mathrm{Al}$ is mainly 


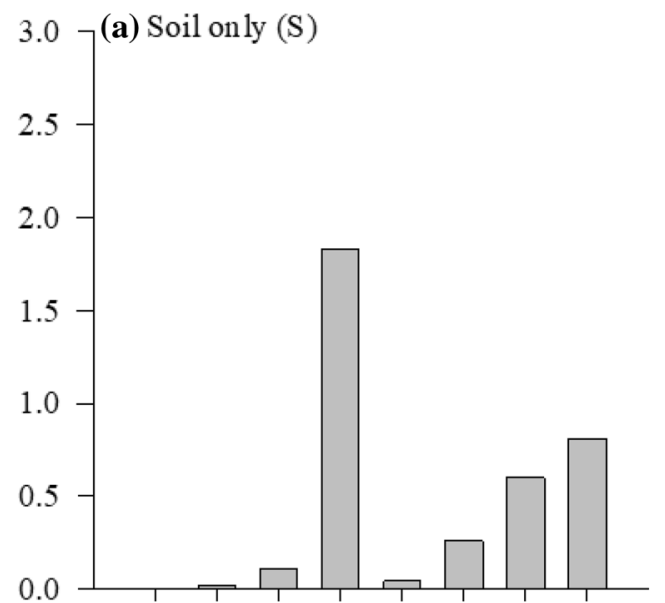

$\mathrm{Pb} \quad \mathrm{Cd} \quad \mathrm{Ni} \quad \mathrm{Al} \quad \mathrm{Cu}$ Mn $\mathrm{Zn} \quad \mathrm{Fe}$
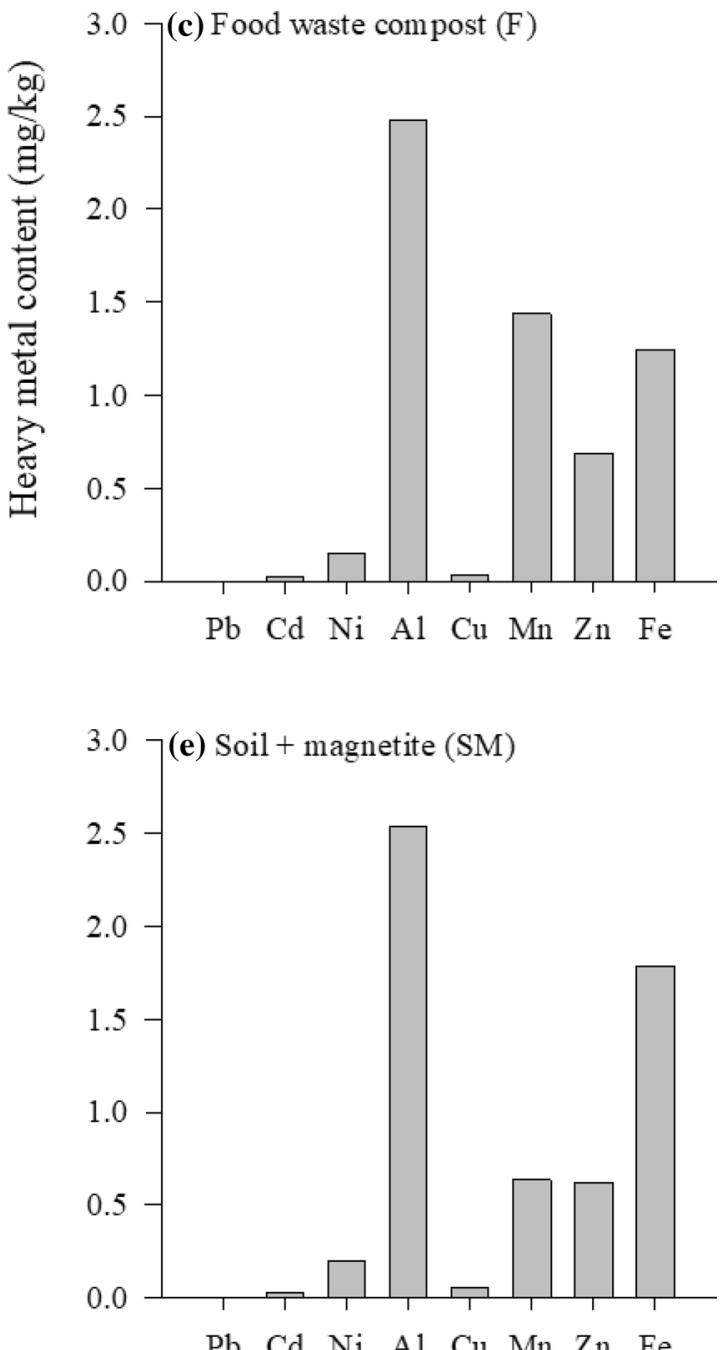

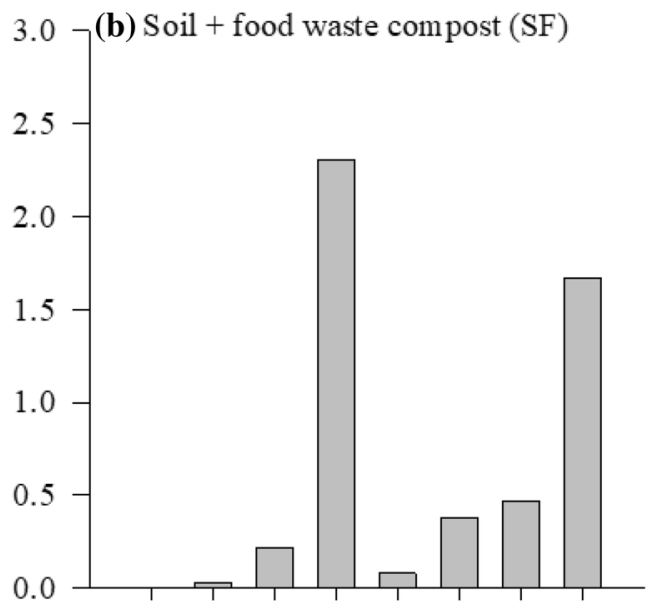

$\mathrm{Pb} \quad \mathrm{Cd} \quad \mathrm{Ni}$ Al $\mathrm{Cu}$ Mn $\mathrm{Zn} \quad \mathrm{Fe}$

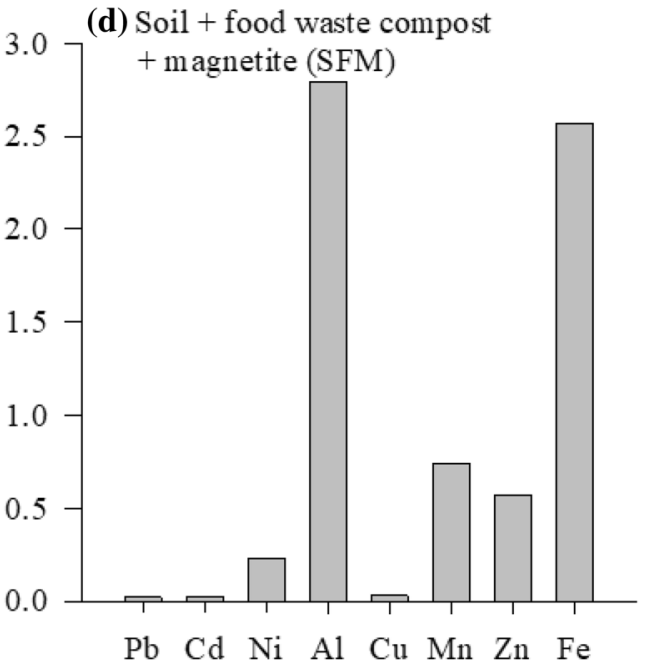

Fig. 7 Heavy metal content in the plant tissue of roselle crops after 127 days from cultivation in five growing media a soil (S), b soil + food waste compost (SF), $\mathbf{c}$ food waste compost $(\mathrm{F}), \mathbf{d}$ soil + food waste compost + magnetite (SFM), and e soil + magnetite (SM) 


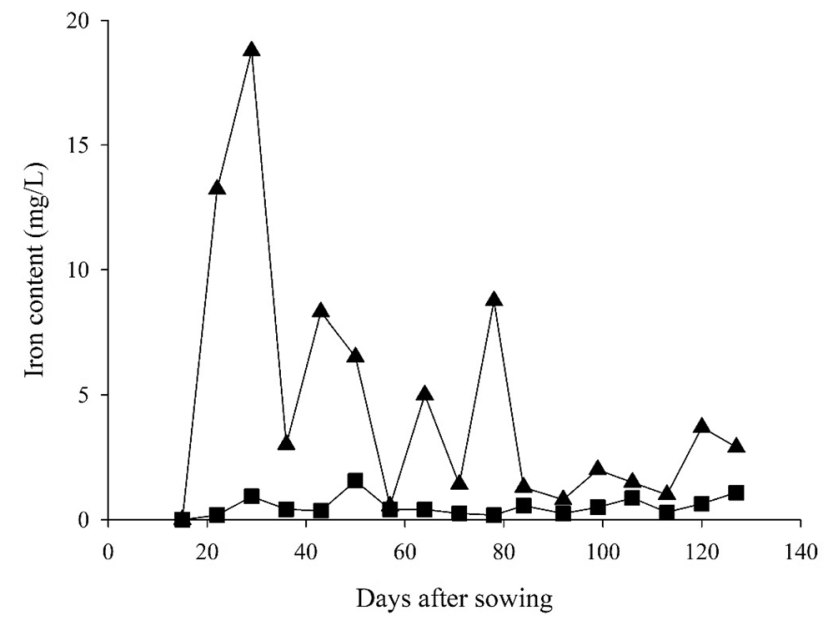

Fig. 8 The amount of iron leaching (mg/L) in SM (filled square) and SFM (filled triangle) pots placed in an open area in Universiti Malaysia Sarawak. SM soil + magnetite, $S F M$ soil + food waste compost + magnetite

accumulated in the roots (underground) compared to aboveground, such as in stems, leaves, and fruits due to its low ability to be transported into higher parts of the plant (Ondo et al. 2017).

The heavy metal concentrations in plant tissues for all elements did not violate the permissible limits of World Health Organization (WHO) guidelines for vegetable crops (Bigdeli and Seilsepour 2008). Thus, roselle plant could be deduced to possess low tolerance to heavy metals. The $\mathrm{pH}$ values of soil (7.1) and FW compost (8.5) that were between neutral and basic would have prevented these heavy metals from being optimally absorbed (Table 4). According to Zheng et al. (2005), elements such as $\mathrm{Cu}, \mathrm{Fe}, \mathrm{Mn}$, and $\mathrm{Pb}$ have great solubility and provide the bioavailability for plant uptake in the region of slightly acidic medium compared to a basic condition. Thus, the low amounts of heavy metals in roselle plant tissues shows that the fruits are safe to be consumed.

\section{Iron leaching test}

Fluctuation of Fe leaching in some weeks could be due to environmental factors, such as rainfall because the pots were placed in an open area. Rain water has been exposed to the pots, which could have contributed to the fluctuating trend of Fe content every week. SFM can be seen to be more dramatically affected by the $\mathrm{Fe}_{3} \mathrm{O}_{4}$ introduction to the medium (Fig. 8). The leachate might contain some amount of medium erosion from the SFM pots due to the texture of FW compost, which was light, aerated, and could easily pass through the cotton cloth into the leachate. This might have caused the higher Fe content in SFM leachate, which was not entirely from the addition of $\mathrm{Fe}_{3} \mathrm{O}_{4}$. SM treatment showed a marginal change in Fe leaching throughout a period of 127 days. Leachate from the SFM was at $18.8 \pm 8.11 \mathrm{mg} / \mathrm{L}$ on day 29 of the highest Fe concentration. Meanwhile, day 57 recorded the lowest concentration of $0.5 \pm 0.43 \mathrm{mg} / \mathrm{L}$ (Fig. 8). SM treatment showed the maximum Fe concentration of $1.6 \pm 1.25 \mathrm{mg} / \mathrm{L}$ on day 50 , while the lowest concentration of $0.2 \pm 0.13 \mathrm{mg} / \mathrm{L}$ was collected on day 78. According to the Ministry of Health in Malaysia (MOH), Fe concentration limit is $1.0 \mathrm{mg} / \mathrm{L}$ for raw water bodies, which is then considered as suitable to be treated as water supply. The Department of Environment (DOE) in Malaysia has outlined the maximum amount of $5.0 \mathrm{mg} / \mathrm{L}$ of leachate discharge as inorganic Fe (Department of Environment 2010). Based on the leaching test, the high concentration of $\mathrm{Fe}$ was deemed unsuitable to be introduced to agricultural areas near water bodies, or water reservoirs to avoid Fe toxicity in water. The high concentration of $\mathrm{Fe}$ could also be attributed to the initial Fe levels present in soil and FW compost.

\section{Conclusion}

The application of FW compost to soil in the ratio of $1: 1$ has resulted in the best roselle plant growth and development. However, it showed no significant difference $(P>0.05)$ for most of the parameters studied. Biologically, there was an increasing trend for leaves, fruits, dry weight, and total leaf surface area due to FW inclusion compared to top soil (S) treatment. Thus, FW compost can be regarded as a useful substitute for commercial fertilizers since it has a significant effect on plant growth. The heavy metal uptake was insignificant for most of the metals studied, except for $\mathrm{Ni}, \mathrm{Mn}$, and $\mathrm{Pb}$ as the roselle plants showed low tolerance to heavy metal mobility to its tissues in different types of treatments. The performance of $\mathrm{Fe}_{3} \mathrm{O}_{4}$ was observed to be similar for all parameters studied compared to its control. Future studies can be performed by incorporating ferrofluid to the soil to increase its binding to the treatment medium. This approach could potentially impose synergistic effects on plant growth compared to the direct application of $\mathrm{Fe}_{3} \mathrm{O}_{4}$ as a solid powder to the treatment medium. In addition, the monitoring of the growth performance will also be continued after 127 days for soil combined with $\mathrm{Fe}_{3} \mathrm{O}_{4}$ due to the promising results. Future work needs to examine the links between the chemical and physical properties of each composting media and plant growth more closely.

Acknowledgements The authors would like to thank Dr Mohd Effendi Wasli and Mr Douglas Bungan for their assistance in nitrogen analysis, as well as Dr Freddy Yeo for provision of plastic pots.

Open Access This article is distributed under the terms of the Creative Commons Attribution 4.0 International License (http://creativeco mmons.org/licenses/by/4.0/), which permits unrestricted use, distribution, and reproduction in any medium, provided you give appropriate credit to the original author(s) and the source, provide a link to the Creative Commons license, and indicate if changes were made. 


\section{References}

Abd El-Azeem SAM, Ahmad M, Usman ARA, Kim KR, Oh SE, Lee SS, Ok YS (2013) Changes of biochemical properties and heavy metal bioavailability in soil treated with natural liming materials. Environ Earth Sci 70(7):3411-3420. https://doi.org/10.1007/ s12665-013-2410-3

Adejumo SA, Ogundiran MB, Togun AO (2018) Soil amendment with compost and crop growth stages influenced heavy metal uptake and distribution in maize crop grown on lead-acid battery waste contaminated soil. J Environ Chem Eng 6:4809-4819. https://doi. org/10.1016/j.jece.2018.07.027

Aja OC, Al-Kayiem HH (2014) Review of municipal solid waste management options in Malaysia, with an emphasis of sustainable waste-to-energy options. J Mater Cycles Waste Manag 16:693710. https://doi.org/10.1007/s10163-013-0220-z

Al-Yousef SA (2013) Antifungal activity of volatiles from lemongrass (Cymbopogon citratus) and peppermint (Menthe piperita) oils against some respiratory pathogenic species of aspergillus. Int J Curr Microbiol App Sci 2(6):261-272

Azim K, Soudi B, Boukhari S, Perissol C, Roussos S, Alami IT (2018) Composting parameters and compost quality: a literature review. Org Arg 8:141-158. https://doi.org/10.1007/s13165-017-0180-z

Baker S, Volova T, Prudnikova SV, Satish S, Nagendra Prasad MN (2017) Nanoagroparticles emerging trends and future prospect in modern agriculture system. Environ Toxicol Pharmacol 53:10-17. https://doi.org/10.1016/j.etap.2017.04.012

Barreira LP, Philippi JA, Rodrigues MS, Satish S, Prasad MN (2008) Physical analyses of compost from composting plants in Brazil. Waste Manag 28:1417-1422. https://doi.org/10.1016/j.wasma n.2007.05.023

Beardsell DV, Nichols DG, Jones DL (1979) Physical properties of nursery potting-mixtures. Sci Hortic 11:1-8. https://doi. org/10.1016/0304-4238(79)90048-7

Bigdeli M, Seilsepour M (2008) Investigation of metals accumulation in some vegetables irrigated with waste water in Shahre Rey-Iran and toxicological implications. J Agric Environ Sci 4(1):86-92

Cerda A, Artola A, Font X, Barrena R, Gea T, Sánchez A (2018) Composting of food wastes: status and challenges. Bioresour Technol 248:57-67. https://doi.org/10.1016/j.biortech.2017.06.133

Chew KW, Chia SR, Show PL, Ling TC, Arya SS, Chang JS (2018) Food waste compost as an organic nutrient source for the cultivation of Chlorella vulgaris. Bioresour Technol 267:356-362. https ://doi.org/10.1016/j.biortech.2018.07.069

Chiroma TM, Ebewele RO, Hymore FK (2012) Levels of heavy metals $(\mathrm{Cu}, \mathrm{Zn}, \mathrm{Pb}, \mathrm{Fe}$ and $\mathrm{Cr})$ in Bushgreen and Roselle irrigated with treated and untreated urban sewage water. Int Res J Environ Sci 1(4):50-55. https://doi.org/10.1080/09593330.2014.993728

Choy SY, Wang K, Qi W, Wang B, Chen CL, Wang JY (2015) Cocomposting of horticultural waste with fruit peels, food waste, and soybean residues. Environ Technol 36:1448-1456. https:// doi.org/10.1080/09593330.2014.993728

Department of Environment (2010) Environmental requirements: a guide for investors. Ministry of Natural Resources and Environment, Bangkok, pp 1-78

Drewry JJ, Cameron KC, Buchan GD (2008) Pasture yield and soil physical property responses to soil compaction from treading and grazing-a review. Aust J Soil Res 46(3):237-256. https://doi. org/10.1071/SR07125

Guidoni LLC, Marques RV, Moncks RB, Botelho FT, da Paz MF, Corrêa LB, Corrêa EK (2018) Home composting using different ratios of bulking agent to food waste. J Environ Manag 207:141-150. https://doi.org/10.1016/j.jenvman.2017.11.031
Jeong J, Connolly EL (2009) Iron uptake mechanisms in plants: functions of the FRO family of ferric reductases. Plant Sci 176:709_ 714. https://doi.org/10.1016/j.plantsci.2009.02.011

Jereme IA, Talib BA, Siwar C, Begum RA (2013) Household food consumption and disposal behaviour in Malaysia. Soc Sci J 8(6):533539. https://doi.org/10.3923/sscience.2013.533.539

Jing J, Rui Y, Zhang F, Rengel Z, Shen J (2010) Localized application of phosphorus and ammonium improves growth of maize seedlings by stimulating root proliferation and rhizosphere acidification. Field Crops Res 119:355-364. https://doi.org/10.1016/j. fcr.2010.08.005

Kalemelawa F, Nishihara E, Endo T, Ahmad Z, Yeasmin R, Tenywa MM, Yamamoto S (2012) An evaluation of aerobic and anaerobic composting of banana peels treated with different inoculums for soil nutrient replenishment. Bioresour Technol 126:375-382. https ://doi.org/10.1016/j.biortech.2012.04.030

Kanakaraju D, Shahdad NRBM, Lim YC, Pace A (2018) Magnetic hybrid $\mathrm{TiO}_{2} / \mathrm{Alg} / \mathrm{FeNPs}$ triads for the efficient removal of methylene blue from water. Sustain Chem Pharm 8:50-63. https://doi. org/10.1016/j.scp.2018.02.001

Kaur S, Singh SR, Tanu S (2017) Utilization of kitchen waste compost as soil amendment for increased crop production. Vegetos 30:238-242. https://doi.org/10.5958/2229-4473.2017.00073.8

King'ori AM (2011) A review of the uses of poultry eggshells and shell membranes. Int J Poult Sci 10(11):908-912. https://doi. org/10.3923/ijps.2011.908.912

Konatea A, Wanga Y, Hec X, Adeela M, Zhang P, Mac Y, Ding Y, Zhang J, Yanga J, Kizitoa S, Ruia Y, Zhan Z (2018) Comparative effects of nano and bulk- $\mathrm{Fe}_{3} \mathrm{O}_{4}$ on the growth of cucumber (Cucumis sativus). Ecotoxicol Environ Saf 165:547-554. https:// doi.org/10.1016/j.ecoenv.2018.09.053

Lin D, Xing B (2007) Phytotoxicity of nanoparticles: inhibition of seed germination and root growth. Environ Pollut 150:243-250. https ://doi.org/10.1016/j.envpol.2007.01.016

Lin CSK, Pfaltzgraff LA, Herrero-Davila L, Mubofu EB, Solhy A, Clark JH, Koutinas A, Kopsahelis N, Stamatelatou K, Dickson F, Thankappan S, Zahouily M, Brocklesby R, Luque R (2013) Food waste as a valuable resource for the production of chemicals, materials and fuels. Current situation and global perspective. Energy Environ Sci 6:426-464. https://doi.org/10.1039/C2EE2 $3440 \mathrm{H}$

Manaf LA, Samah MAA, Zukki NIM (2009) Municipal solid waste management in Malaysia: practices and challenges. Waste Manag 29(11):2902-2906. https://doi.org/10.1016/j.wasman.2008.07.015

Moh YC, Manaf LA (2014) Overview of household solid waste recycling policy status and challenges in Malaysia. Resour Conserv Recycl 82:50-61. https://doi.org/10.1016/j.resconrec.2013.11.004

Morikawa CK, Saigusa M (2011) Recycling coffee grounds and tea leaf wastes to improve the yield and mineral content of grains of paddy rice. J Sci Food Agric 91:2108-2111. https://doi.org/10.1002/ jsfa. 4444

Muehe EM, Adaktylou IJ, Obst M, Zeitvogel F, Behrens S, PlanerFriedrich B, Kraemer U, Kappler A (2013) Organic carbon and reducing conditions lead to cadmium immobilization by secondary $\mathrm{Fe}$ mineral formation in a pH-neutral soil. Environ Sci Technol 47(23):13430-13439. https://doi.org/10.1021/es403438n

Namkoong W, Hwang E-Y, Park J-S, Choi J-Y (2002) Bioremediation of diesel contaminated soil with composting. Environ Pollut 119:23-31. https://doi.org/10.1016/S0269-7491(01)00328-1

Ondo JA, Eba F, Zita H, Membetsi M, Biyogo RM, Ndzoungou D (2017) Soil solution aluminium, and nutrient and aluminium uptake in Hibiscus sabdariffa under nitrogen and phosphorus fertilizers. Commun Soil Sci Plant Anal 48:1636-1645. https:// doi.org/10.1080/00103624.2017.1373795

Pandey AC, Sanjay SS, Yadav RS (2010) Application of ZnO nanoparticles in influencing the growth rate of Cicer arietinum. J Exp 
Nanosci 5(6):488-497. https://doi.org/10.1080/174580810036496 48

Parisi C, Vigani M, Rodríguez-Cerezo E (2015) Agricultural nanotechnologies: what are the current possibilities? Nano Today 10:124-127. https://doi.org/10.1016/j.nantod.2014.09.009

Petersen SO, Henriksen K, Mortensen GK, Krogh PH, Brandt KK, Sørensen J, Madsen T, Petersen J, Grøn C (2003) Recycling of sewage sludge and household compost to arable land: fate and effects of organic contaminants, and impact on soil fertility. Soil Tillage Res 72(2):139-152. https://doi.org/10.1016/S0167 -1987(03)00084-9

Ronga D, Pane C, Zaccardelli M, Pecchioni N (2016) Use of spent coffee ground compost in peat-based growing media for the production of basil and tomato potting plants. Commun Soil Sci Plan 47(3):356-368. https://doi.org/10.1080/00103624.2015.1122803

Ruggieri L, Gea T, Artola A, Sánchez A (2009) Air filled porosity measurements by air pycnometry in the composting process: a review and a correlation analysis. Bioresour Technol 100:26552666. https://doi.org/10.1016/j.biortech.2008.12.049

Shen J, Yuan L, Zhang J, Li H, Bai Z, Chen X (2011) Phosphorus dynamics: from soil to plant. Plant Physiol 156:997-1005. https ://doi.org/10.1104/pp.111.175232

Sutari W, Sumadi Nuraini A, Hamdani JS (2018) Growing media compositions and watering intervals on seed production of potatoes G2 grown at medium altitude. Asian J Crop Sci 10:190-197. https ://doi.org/10.3923/ajcs.2018.190.197

Uddin ABMH, Khalid RS, Alaama M, Abdualkader AM, Kasmuri A, Abbas SA (2016) Comparative study of three digestion methods for elemental analysis in traditional medicine products using atomic absorption spectrometry. J Anal Sci Technol 7:6. https:// doi.org/10.1186/s40543-016-0085-6

Wang H, Kou X, Pei Z, Xiao JQ, Shan X, Xing B (2011) Physiological effects of magnetite $\left(\mathrm{Fe}_{3} \mathrm{O}_{4}\right)$ nanoparticles on perennial ryegrass (Lolium perenne L.) and pumpkin (Cucurbita mixta) plants. Nanotoxicology 5(1):30-42. https://doi.org/10.3109/17435 390.2010 .489206

Waqas M, Nizami AS, Aburiazaiza AS, Barakat MA, Rashid MI, Ismail IMI (2018) Optimizing the process of food waste compost and valorizing its applications: a case study of Saudi Arabia. J Clean Prod 176:426-438. https://doi.org/10.1016/j.jclep ro.2017.12.165

Wuana RA, Mbasugh PA (2014) Response of roselle (Hibiscus sabdariffa) to heavy metals contamination in soils with different organic fertilisations. Chem Ecol 29(5):437-447. https://doi. org/10.1080/02757540.2013.770479

Zheng L, Hong F, Lu S, Liu C (2005) Effect of nano- $\mathrm{TiO}_{2}$ on strength of naturally aged seeds and growth of spinach. Biol Trace Elem Res 105:83-91. https://doi.org/10.1385/BTER:104:1:083

Zhu H, Han J, Xiao JQJY (2008) Uptake, translocation, and accumulation of manufactured iron oxide nanoparticles by pumpkin plants. J Environ Monit 10:713-717. https://doi.org/10.1039/b805998e

Publisher's Note Springer Nature remains neutral with regard to jurisdictional claims in published maps and institutional affiliations. 